\title{
Discursive and Cultural Encounters in Ahmad bin Qasim Al-Hajari's Ambassadorial Travel Narrative, Kitab Nasir Adin ala alqawm al-kafirin
}

\begin{abstract}
By Lahoucine Aammari*
The ambassadorial travel text of the Andalusian Morisco, Ahmad bin Qasim (AlHajari), The Book of the Protector of Religion against the Unbelievers (Kitab Nasir Adin ala alqawm al-kafirin), is about the author's intellectual, cultural and theological interactions with the Christians in France and Holland at the beginning of the 17th century. Viewing his journey/border-crossing as an act of theological and intellectual "jihad" against equal adversaries, Qasim's highly polemical disputations with his religious counterparts are solidly based on what he sees as a corrective reading for them of the Bible, for he rebuts them not on the basis of the Qur'an only, but of the Bible as well, which, Qasim argues, they have either misunderstood or falsified. The Moroccan emissary went to Europe with a sense of angst, showing his vituperative fulminations on the Christians. As an eyewitness of the Moriscos' convert-or-leave dreadful ordeal and of their exaction and expulsion, Qasim did his best to mould his coreligionists' tragedy and to cast light on one of the most infamous episodes in Spanish history.
\end{abstract}

Keywords: Ahmad bin Qasim, Muslims-Christains relations, the Book of the Protector of Religion against the Unbelievers, the Moriscos, travel narrative.

\section{Introduction}

There are many Moroccan travellers-cum-envoys who journeyed to Europe in different periods of time starting practically from the last quarters of the sixteenth century till the outset of the twentieth century. Muslim travellers, merchants, ambassadors, factors and petitioners from North Africa ventured to different European capitals to negotiate the furtherance of commercial and diplomatic ties and many other issues beside. These envoys visited and wrote about Spain, France, the Low Countries, Italy, England, and Malta. They went to confer commercial and peace treaties, ransom captives, seek restitution and/or demand compensation for losses incurred at sea. Ahmed bin Qasim's voyage, among others, is a conspicuous example on which we can rely to refute Bernard Lewis's thesis of Muslim travellers' lack of interest in the Christian other, postulating that travelling is a feature which is inherent in Western Christians (Lewis 1993).

Ahmed ben Qasim's text is subsumed within ambassadorial travel literature, a genre which is difficult to define because of the slippery aspect of the genre and because of its interdisciplinary nature. This difficulty in determining this

\footnotetext{
* Teacher-PhD Researcher, University of Sultan Moulay Slimane, Faculty of Arts and Humanities, Beni Mellal, Morocco.
} 
nascent genre can be attributed to the fact that the last decades of the $20^{\text {th }}$ century and the outset of the $21^{\text {st }}$ century have undeniably witnessed a boom of travel writing as it has been taken seriously in universities only in the past three or four decades, and this boom will not surely subside in the future. Because it is under theorized, travel writing has seen a myriad of controversies concerning its definition. Right after the 1950s which coincided with the rise of postcolonial theory, this genre "was usually dismissed by literary critics and cultural commentators as a minor, somewhat middle-brow form" (Thompson 2011: 2). In spite of all these criticisms, the genre has proven outstandingly immune and it becomes one of the most popular and widely read forms of literature today.

In this context, we can forge a question thus: why was there a great interest in travel literature as a literary genre at the last decades of the $20^{\text {th }}$ century and the outset of the $21^{\text {st }}$ ? What makes travel writing on the increase is its paradigmatic reflection of the human (post)modern condition in the 1950s and afterwards. Post-modern theorists have directed their attention to travel "for its expression of the themes and condition of exile, migration, nomadism, and boundary-crossings" (Youngs 1997: v). Under such circumstances, travel writing has acquired a new relevance and prestige as a genre that can provide important insights into the often fraught encounters and exchanges currently taking place between cultures, and into the lives being led, and the subjectivities being formed and the identities being negotiated, in a globalising world.

Over the same period, academic interest in travel writing has also burgeoned dramatically. This revival of critical interest of the genre coincides with the rise of postcolonial theory. The latter was directed at the recuperation of marginal books which were either stylistically or culturally "left out" of canons. In fact, in the past few decades, literature of and on travel has reached enormous scale. A number of reasons can be assigned for its popularity. Bill Buford attributes it to its "wonderful ambiguity" lying "between fact and fiction." It can be considered as "postmodern collage" encompassing and intersecting diverse pieces. Different academic disciplines have employed travel for different reasons.

Scholars and critics working in several different disciplines have found the genre relevant to a broad range of cultural, political and historical debates. These critics adopt a critical approach to travel writing, so the publication of critical studies rises sharply such as Dennis Porter's Haunted Journeys (1991), Eric Leed's The Mind of the Traveler (1991), Mary Louise Pratt's Imperial Eyes (1992) and David Spurr's The Rhetoric of Empire (1993). This is a development especially associated with the spread of what has come to be termed "postcolonialism", or "postcolonial studies" in many branches of the humanities and social sciences. Since its entry into the mainstream in the late 1980s with the publication of The Empire Writes Back, there has been a constant flood of "introductions" to the field of postcolonialism, most of them focusing on the work of the "colonial discourse" theorists and pacesetters: Edward Said, Homi K. Bhabha and Gayatri Spivak. For Bill Ashcroft, in his Postcolonial Transformation, "Post-colonialism means many things and embraces a dizzying array of critical practices" (2001: 7). 
Most of the studies about travel literature have coped with the journey of European travellers to the Orient/ Islamic countries, Dar al-Islam or "abode of Islam", and there are meagre studies about the travellers who make the journey from the "abode of Islam" to the "abode of disbelief" or dar al-Kufr. As far as Morocco is concerned, there are a number of travellers, envoys, merchants, ambassadors and clergymen who sojourned in the land of the Christians and recorded what they encountered and witnessed by writing tomes after tomes. These travellers are far removed from their European counterparts. The latter, especially British and French ones, travel to Morocco with different missions and reasons in mind depending on the role of each traveller; we can find among them the soldier, the spy, the adventurer, the sailor, the buccaneer, the journalist, the diplomatist, the painter, the colonialist, the globetrotter and so on, and most of their accounts and records are practically freighted with some stereotypical accounts and subjective vignettes (Nabil Matar 2003b, Pratt 1992). These travellers did their best to energize the myths of empire, its discursive apparatuses and ideological grandiloquence; their travel accounts, records, tableaux and memoirs serve as the main fodder for the colonizers in their assiduous attempts for land-grabbing. In his In the Lands of the Christians, Nabil Matar argues:

The travelers wrote informative accounts that stand in contrast to many of the European descriptions of the Muslim world in the same period. Travelers from Europe to North Africa and the Levant, whether they came from countries with an extensive medieval history of contact $[\ldots]$ or countries of Renaissance interaction...often carried with them ideological and polemical baggage that burdened their accounts. They claimed to see what they never encountered, and interpreted authoritatively to their readers what they never understood. (2003b: xxxi)

The Moroccan travelers, on the other hand, made their journeys as the envoys of Moorish Sultans and kings. Hence, they should report in detail and in most objective manner what they encountered and witnessed in the lands of the Christians during their peregrinations. They did not virtually fabricate information as their European counterparts mostly did, but they recounted what they saw with precision as they should impart their reports wrote to their governments. Their accounts are, thus, characterized by their accuracy; when Qasim was in France, he told a French man that he should report to the Moorish Sultan what he witnessed there in France with accuracy: "So I said 'Know that I am the translator for the Sultan of Marrakech. Whoever fills the position needs to be well read in both Islamic and Christian sources in order that he be able to respond to and translate in the presence of the sultan. Had I been in the presence of the learned men of our religion, I would not have felt competent to discuss such matters'" (Matar 2003b: 11).

Moroccan travellers and emissaries are erudite and they have encyclopedic knowledge, so to speak, because they are carefully chosen by the Sultan or the superior governors; they are knowledgeable in politics, religion, and culture and in other domains. To exemplify, when Ahmad bin Qasim was in a mission 
to Holland (1611), whose account is the fulcrum of this article, a Dutchman said to him, "we are amazed at you: you know languages, read books, and have travelled in the cities and the countries of the world. And yet, you are a Muslim!" (Matar 2003b: xiii). When we read this travel account, we discover that as the title of the account openly points out there is religious difference, that is why most of Moroccan travellers sharply criticized what they saw in the land of the Christians as irreligious, sacrilegious and non-Islamic.

In this article, the focus will be on the ambassadorial travel narrative of the Andalusian-Moroccan emissary, Ahmad bin Qasim (Al-Hajari), to France and Holland at the beginning of the seventeen century (1611-1613). The travelogue, The Book of the Protector of Religion against the Unbelievers (Nasir Adin ala alqawm al-kafirin), ${ }^{1}$ is about Al-Hajari, who went to France and Holland to restitute the possessions of his expelled coreligionists, a diplomatic mission that was an immediate outcome of the violent political and religious decision of Moorish expulsion from Andalusia, accompanied as it was by other processes of humiliation and extermination. Besides, the travel account reveals the main implications of his intellectual, cultural and theological interactions with the Christians. As a Muslim from "abode of Islam" and as a Morisco in bilad alnasara (the land of the Christains), Qasim was virtually rebuffed by Christains as a strange "other". In this vein, the first section will focus on Ahmad bin Qasim and his travelogue (Rihlah). Second, I deal with the main discursive and cultural encounters the author deploys in his polemical debates and disputations with his religious counterparts while in "land of the Christians". Finally, I explore Qasim's dramatization of the Moriscos' plight, their double identity in Spain, their expulsion from Al-Andalus as persona non grata and how forced religious and cultural absorption and assimilationist model are an ineffective and even counter-productive response to security fears. This historical fact is percolated down into contemporary times, being reverberated widely with the emergence of the Extreme Left in different European countries and its racist attitudes towards Mulsims and Arabs as a culturally, socially and religiously different Other.

\section{Ahmad bin Qasim and his Expelled Coreligionists}

Ahmad bin Qasim bin al-faqih Qasim bin Shaykh Al-Hajari al-Andalusi (ca. 1570 - ca. 1650). He was nicknamed "Abi Laabas" and also "Chihabdin Afuquay Boukharanou", whereas the Christian name he was obliged to take before being expelled from Andalucia was "Diego Boukharanou". When he was young he worked as a translator from Arabic to Spanish. He managed to have solid knowledge of Arabic notwithstanding threats-cum-pressures wreaked upon any Morisco discovered learning Arabic. The Al-Andalusi mastered Spanish and he outwardly practiced his religious rites as a New Christian, but

\footnotetext{
${ }^{1}$ Throughout this article, I make use of Nabil Matar's translation of the envoy's ambassadorial travel account, in his book In the Lands of the Christains (2003). So all quotes are taken from his book.
} 
he stealthily dissimulated his rigid adherence to Islamic faith (Matar 2003b: 6, Al-Qaddouri 1995: 40). Regardless of being recognized skilful, he made up his mind to flee from the land of the Morisco circa 1598, at the age of 28, in a very hard journey in the light of constraints that the Spanish imposed on the Moriscos. He masqueraded as an old Christian, and he managed to navigate from the port of Santa Maria in Cadiz to Mazagan Port in Portugal. He was received by the famous Sa'dian Sultan, Ahmad Al-Mansur, who figured out his skills and capacities. He went straight to Marrakech working as a translator of the Court for the Moroccan Sultan Moulay Zaydan. He decided to leave Morocco because of the constant frictions and conflicts that occurred between different Moriscos in some Moroccan cities such as conflicts occurring between the Moriscos of Salé Kasbah and Mohamed Laayachi and his group, who accused the former of plotting with the Christians. After leaving Morocco about 1635, he settled in Tunisia. After that he made a Pilgrimage to Mecca.

The decision to expel the Moriscos followed more than a century in which Spain's rulers tried to uproot not just the Islamic religious beliefs of the Moriscos, but their socio-cultural traditions and customs. Under such circumstances, Qasim felt that he no longer stayed in his country and should flee to "God and the land of Islam". Qasim went to Marrakech where he met the celebrated Moulay Ahmad Al-Mansur on July 4, 1599. Impressed by Qasim's intelligence and erudite knowledge, Al- Mansur's successor Moulay Zaydan (r. 1603-1618) appointed the émigré/exile as his official translator. For Matar, Philip III of Spain ordered the expulsion of the Moriscos/Andalusians in 1609. On their way to Morocco, those who decided to leave were robbered blind on board the Christian ships, so Al-Hajjari went to France and Holland to restitute the possessions of his expelled coreligionists, a diplomatic mission that was an immediate outcome of the violent political and religious decision of Moorish expulsion from Andalusia, accompanied as it was by other processes of humiliation and extermination. Qasim sailed from Safi, Le Havre, and then continued to Rouen, arriving in Paris in April or May of 1612. He then continued to Bordeaux, St Jean de Luz, and then back to Paris (Matar 2003b: 6).

Towards the end of the fifteenth century and with pinnacle of the Age of Exploration, Europe broke out of its long confinement. We can identify two sets of factors - the first, material or physical; the second, cultural - that had bottled up Europe for so long. A principal factor in this was that, after the seventh century A.D., "sea routes and land-routes alike were barred by the meteoric rise of Islam, which interposed its iron curtain between West and East" (Latham 1958: 8). Besides, all Christians' attempts to beset this "infidel threat", that is Islam, were for a time unsuccessful. European formation of cultural imaginary about the Oriental Other started to get its momentum in this period as well. Marco Polo's Travels with its tales of the stunning wealth of the East played a decisive role in spurring and sparking off the European imagination to search for a westerly route to the East, a search that became increasingly important. For soon the eastern opening became virtually threatened again by the rise of a new Islamic power, the Ottoman Empire. 
The second major impediment to the Orient was cultural. Europeans made certain cultural imaginations of the outside world and they conceptualized and imagined it in a very peculiar mould. When they gazed at their global map and looked to the south, they figured out that there lay the shifting empires of Islam, which, despite their early tolerance of the Christians and the Jews, had advanced deep into Europe - to Poitiers and Constantinople, across North Africa and Spain, Portugal and Southern Italy. All that lay beyond Europe was thought in the light of a hazy mixture of fact and fantasy, a myriad of sources of knowledge and "a library or archive of information" (Said 1978: 41-42). Europe had accumulated about their view of the other: classical knowledge, mythology, biblical and religious sources as well as travellers' accounts. All these apparatuses can be subsumed within Orientalism as a discourse of the West about the East. In this context, Edward Said contends that

My contention is that, without examining Orientalism as a discourse, one cannot possibly understand the enormously systematic discipline by which European culture was able to manage - and even produce - the Orient politically, sociologically, militarily, ideologically, scientifically and imaginatively during the post-Enlightenment period. Moreover, so authoritative a position did Orientalism have that I believe no one writing, thinking, or acting on the Orient could do so without taking account of the limitations on thought and action imposed by Orientalism. (1978: 3)

Said goes on to argue that, "in a sense Orientalism was a library or archive of information commonly [...] held. What bound the archive together was a family of ideas and a unifying set of values proven in various ways to be effective. These ideas explained the behaviour of Orientals; they supplied Orientals with a mentality, a genealogy, an atmosphere; most important, they allowed Europeans to deal with and even to see Orientals as a phenomenon possessing regular characteristics" (Said 1978: 41-42).

According to Wallerstein (1979), the modern world-system is divided into three components: the core/the metropolis (initially located in north-west and central Europe); the semi-periphery (the Mediterranean zone after its decline from earlier prominence); and the periphery (colonized and captured territories), although where each of these three components is located has varied over time. For Europeans writers, modernity emanates from the first component of the world-system; that is, from the centre or the metropolis. There was the creation of tools and whitewalls (cultural, social, ideological and economic) through which the Europe would sustain its Eurocentrism and deepen it and exclude the "other" from all the processes of building civilizations. On the other hand, feudalism, barbarism, darkness and primitivism are aspects which are intrinsically dovetailed with the last two components of the world-system.

In his travelogue, A Journey to Mequinez, the British traveller, John Windus, notes that "the very people whom, since their expulsion from Spain, we have justly called barbarous, from their cruelty, pride, and inveteracy against the Christian name, and are famous for their craft and insincerity, as the old 
Africans were reckoned by the Romans"( 1725: xv). Windus's clarification denotes that the Barbary discourse was born in the aftermath of the Reconquista, a time when Islamic-Christian relations plummeted and when a Muslim force materialised in North Africa to challenge European aspirations for supremacy in the western basin of the Mediterranean. Barbary piracy and slavery were in this respect interpreted simply as savage acts of vengeance, a view that prevailed until the twentieth century (Lane-Poole 1890: 8-10). Investigating captivity experiences in the seventeenth and eighteenth centuries, Linda Colley writes that the British then commonly used Barbary as a "blanket term" for the North African region and its various peoples, Arabs, Berbers, Moriscos, Ottoman soldiers and officials and more, adding that "the assonance between Barbary as a geographical signifier and the insult 'barbarian' was a gift of which generations of polemicists made abundant and predictable use" (Colley 2002: 44). The blanket term and its connotative baggage were indeed used abundantly across Europe.

The married couple Queen Isabella of Castile and King Ferdinand of Aragon as two "Catholic Monarchs" completed the subjugation of Granada, the last Muslim state in Iberia. Although a large Muslim population remained in the peninsula, these people were now totally subject to their Christian rulers. However, this triumph was not enough to assuage the crusading zeal of Spaniards. Plans were put forward to carry the holy war to Muslim North Africa through an amphibious invasion.

Some critics ${ }^{2}$ claim that the Europeans went to the Mediterranean to barter, trade or even pillage victuals, not to seize and settle. These critics deem that the Europeans' attacks on North Africa were not really invasions, but retaliations against the "pirates" who took European captive. Against these critics' contention, and in his The Mediterranean and the Mediterranean World in the Age of Philip II, Fernand Braudel (1972-1973) sees the British and the French presence in the Mediterranean as a kind of "Northern Invasion". Braudel's assertion is endorsed by Nabil Matar and Daniel Goffman. The latter critic observes that Europeans first "burst into the Mediterranean world, not as merchants but as pirates" (Goffman 1990:137). Additionally, Goffman regards Europeans as colonists because although Britain was far behind Spain and Portugal in the conquest of North Africa, with the 1661 occupation of its first territory in the Islamic World, Tangier, King Charles II, hoped to "expand into the comparatively fertile region beyond the sandhills," ${ }^{3}$ intent on building an empire that was to last "a thousand years." ${ }^{4}$ The 1678 treaty with Salé confirmed that Britons were planning to extend themselves into Europe, Asia, Africa and America. It is not

\footnotetext{
${ }^{2}$ See Molly Greene, however, who qualifies Braudel, "Beyond the Northern Invasion: The Mediterranean in the Seventeenth Century," in Past and Present, 174 (2002): 42-71. And see the essay by Maria Fusaro, "After Braudel: a Reassessment of Mediterranean History between the Northern Invasion and the Caravan Maritime," and Colin Heywood, "The English in the Mediterranean, 1600-1630: A Post-Braudelian standpoint on the "Northern Invasion," in Trade and Cultural Exchange, eds. Fusaro et al., 1-23 and 23-45 respectively.

${ }^{3}$ The Straights Voyage or St Davids Poem by John Baltharpe, ed. and introd. J.S. Bromley, xxvii. P.4

${ }^{4}$ As the 1663 Charter for the Company of Royal Adventurers into Africa by Charles II stated: Select Charters of Trading Companies, A.D. 1530-1707, ed. Cecil T. Carr (London, 1913), 179.
} 
a coincidence, therefore, that the highest number of European captives in the Mediterranean and the Atlantic in the period came from among the peoples of imperial trade and expansion: British, French, and Spanish all of whom established colonial outposts in North Africa (Matar 2014: 160).

Although English piracy might seem like a romantic, individualistic response to the age of empire-formation, it existed in a complicated web of geopolitical and religious exchanges. Piracy in the sixteenth century was hardly an isolated phenomenon. Fernand Braudel refers to it as "that secondary form of war" another way of fighting the battle between Christianity and Islam. But the religious motivations for piracy were largely cosmetic; the true stakes were economic. Every nation that attempted to trade in the Mediterranean faced the scourge of the Barbary pirates, who became increasingly well organized and powerful as the century progressed. The economic motive was in turn connected to the territorial struggles in the area, for once the Barbary States came under the control of the Ottoman emperor, an increase in piracy essentially equalled an advance by the Turk.

The land of the Farthest West was seen as inimical to the Christendom world as it was a real threat to its navigational activities in the Mediterranean Sea by the practice of piracy. During this period, the Mediterranean was infested with pirates and privateers from all countries and religions. Captivity narratives and accounts are the most illuminating form of Barbary story-telling. This mode of writing flourished and burgeoned throughout Western Europe and in North Africa from the-mid sixteenth century into the nineteenth century, which coincided with the French occupation of Algeria, and it provided detailed information about the customs, flora and fauna and cultural markers as well as it sparked off and conjured up the geo-historical awareness of the British about Western Barbary and advertised the horrors of the Barbary captivity to the English reading public. These Barbary corsairs reached their climax in the seventh century. For G. N. Clark, "the seventeenth century was one of the twelve during which, in spite of what geographers, might regard as probable and proper, the two sides of the Mediterranean were in the hands of two separate and inimical civilizations, different in religion, morals, law, economy and knowledge" (1944: 22).

The North Africans fought against the incursion of the European merchant fleets by capturing travellers, men, women, sailors, enslaving their crews, and forcing them to a miserable life of bondage and toil. There are hundreds of people which were captured. According to Linda Colley, "between 1622 and 1640s, privateers based in North African powers seized at least three hundred English, Scottish, Irish and Welsh trading vessels operating in the Mediterranean and Atlantic" (2002: 4). These are recurrent images that will fix the Moor over and over as a monstrous, inhuman other, projecting onto the home communities an image of a fearful and dangerous region, and making the above-mentioned clichés ineradicably deep-seated.

In the light of such turbulent events, Spain was much obsessed by the presence of the Turks in the Mediterranean basin at the end of the sixteenth century and the outset of the seventeenth century, mainly because of the existence 
of Moriscos as a minority in Spain (Abdeljalil Tamimi 1989). This minority was targeted by the Spanish kings. At the onset of the seventeenth century, they stated it was useless to integrate this minority in the Spanish society regardless of all those inexorable efforts to Christianize them. The Spanish King, Philip III, stated in his letters to some governors of Spain that Moriscos were just frauds and hypocrites, for they seemed Christians but in real fact they stuck to their religion, Islam. On 22 September 1609, Philip III ordered all Moriscos to leave Spain and he gave them three days to do so. This negative attitude towards the Moriscos can be attributed to the fact that there was a kind of competition between Spain as a Catholic country which tried to impose its dominance on the Mediterranean basin and the Ottoman Empire that did its best to spread Islam and show its supremacy. The Turks felt that they should gather all Muslims as the Turks regarded themselves as Caliphates of Muslims, especially after their entrance into Egypt in 1517. The Spanish fright continued, especially when they figured out that the number of Muslims was in the increase. The Spanish accused the Moriscos of conspiring with the Ottomans to get back Andalusia. Spain was in constant fear of the movements of the Ottoman Empire. To avoid this, the Spanish King, Philip III, ordered that the Moriscos were to be expelled from Spain in 1609.

The last quarters of the sixteenth century witnessed the solidification of the Anglo-Moroccan relations under the reign of Queen Elizabeth I (r. 1558-1603) and the Sa'dian King, Moulay Ahmad Al-Mansur (r.1578-1603). In the turbulent years after her excommunication in 1570, and until the very end of her reign, Elizabeth was much in need of an ally such as Al-Mansur, especially since she saw before her a determined adversary, Philip II, whose vast New World resources of gold and silver were matched by his antipathy to the Protestant heresy. The two sovereigns exchanged letters concerning the naval support of each other to help the Moroccan King to restore Al-Andalus from the Spaniards and Elizabeth I, the protestant, showed her endorsement.

\section{Ahmed ibn Qasim's Discursive and Cultural Encounters with Otherness}

Burdened with the Moriscos' nostalgic reminisces and their dreadful plight, Ahmad ibn Qasim travelled to Europe, and his travelogue, Nasir Adin ala alqawm al-kafirin (1611-1613), is a sad reflection of this terrifying ordeal. He showed in his travelogue his vituperative attack on the Christians. For Nabil Matar,

The psychological impact of the arrival, from 1609 to 1614 , of hundreds of thousands of frightened and embittered men, women, and children who had been driven out of their European homes because of their Islamic Faith, or the racial residues of that faith, permanently changed Arab and Islamic views of Europeans. After their expulsion, the Moriscos settled in Tunisia, Algeria and Morocco and told the local inhabitants about the burnings, rampages, tortures, and exile they had suffered at the hands of the Christians. (2003b: $\mathrm{xx}$ vii) 
The envoy's journey (Rihla) is a record of his theological, cultural and discursive encounters with the Christians of France and Holland. Qasim represents his religious counterparts through the deployment of certain discursive strategies that make the author in a preferable and superior position vis-à-vis his Christian interlocutors. The envoy writes from a superior perspective on the grounds of his piety, rigid adherence to and fondness of his faith. In this vein, there is the predominance of a style which is premised upon polemics, arguments and dialogues. At the outset of encounter with the Christians, the debate sounds quite normal, but it suddenly declines to a theological cul-de-sac whenever the issue of religion is in dispute. Because of the argumentative aspect of Nasir Adin ala alqawm al-kafirin, the sentences are short and terse and the author deploys the words "I said", "he said" or "she said" extensively in an attempt to make the reader play a part in discussions and debates, prodding him or her, thus, to sympathise and empathise with the emissary and with the Moriscos' cause.

Qasim's travel account presents riveting instances of disputations and debates which the author made with his religious counterparts, winning his discussions and making them almost successful. In the following debate, the author exposes the general atmosphere concerning his debate with a French woman of noble blood:

A girl from the nobility came from the city of Fontenay to visit an idol near the house where were staying [...]. After food was served, they invited me and offered me a chair. So I sat down with the wife of the commander to my right, and the girls in front of me, including the one who had come to visit. She was more beautiful and elegant than the one in the house, and her clothes, along with two maids who served her, showed her to be of the nobility. Before inviting me, they had told her about me. (Nabil Matar 2003b: 17)

After introducing this general scene, Al-Hajari makes the reader ready for the oral controversy, describing the ill feeling of his foe/interlocutor: "When she sat down, she looked disdainfully at me, and her face showed her hostility." After this prologue, the author opens the debate, thus:

"Are you a Turk?" she said

"A Muslim, praise to be God," I said to her.

"How come you do not know God?" she said.

"Muslims," I said to her, "know God better than you."

"Better than we?" she said.

"Yes," I said to her.

"What is your proof?" she said to me. (Nabil Mata 2003b:17, al-Qaddouri 1995: 40)

The emissary looks at the French notable a while, pointing out that outdoing these Christians in such a thorny issue requires solid arguments and deep knowledge of both the Old and New Testament, which he had already read in 
Arabic and Spanish. Qasim saw that the French girl held a book under her arm containing the Ten Commandments. He told her to open the book and to have a look at them and read the first one which goes thus: "God Almighty said, Do not carve statues, and do not worship them. Worship God alone." When she had read it, Qasim went on the attack against her as follows:

I said to her "Muslims don't carve statues and do not worship them."

She said, "We do not worship the idols themselves, but what the idols represent."

"I could answer you about representation and the represented," I said to her, "but let us move to another problem to which you have no answer." [As if the author wants to show the reader that this woman is incapable of debating over this issue]

"The divine Commandment," I said to her, "in the text: Do not make statutes and do not worship them?"

"Yes," She said.

"Do you or do not make idols?" I said to her. (Matar 2003b:17-18)

Here, at this moment, there is a swerve in the discussion, and the author outdoes his enemy: "She had to give in to reason and truth. So she looked at the women and said in their language: 'He won. I cannot find anything with which we can answer him.' So I looked at her, and found that she was now happy and relaxed, as if a veil had been removed from her heart" (Matar 2003b: 18).

While in the French city, Bordeaux, Qasim made some discussions with a judge named Fayrad, who said to the author that "We have it in our books that the Muslims visit Mecca to see their prophet in the middle of an iron hanging in the air." The traveller replied by saying "Is it permissible in your religion for someone to lie and insult the religion of another in order to glorify his own religion and magnify it before his own coreligionists?" (Matar 2003b: 24). Then, the judge asked Qasim some questions about paradise:

"There is another matter," he said. "You Believe that the inhabitants of paradise eat and drink and enjoy there what they have on earth?"

"even our Sayyid Issa, peace be upon him," I said to him, " did not deny that, saying in the Gospel: "As for the juice of this tree - I mean the juice of grapevine - I will not drink it again on earth until I drink it with you in the kingdom." Is this [not] in your Gospel?"

"Yes," he said.

"And why do you deny it?" I said. (Matar 2003b: 25)

To underscore the superiority of the "Self" over the "Other", Qasim demonstrated that the Christian judge was unable to justify his claim and pretence; "The Judge continued to reflect on what to say, but he did not find anything. And he was one of their top scholars." In the light of these dialogues and controversial instances, it occurs to us the way the author writes to convince his religious counterparts and to make a corrective reading of the Bible as it 
was falsified by them. He overuses the verb "say"; the peculiar deployment of this verb is not at random, but rather it is used to receive the attention of Muslim scholars of the cultural atmosphere that permeated at that time in Europe. The latter's scholars were eager to know everything about Islamic societies. Indeed, the centralized monarchies of France, England and Spain were emerging. Europe was on the threshold of a long, secular boom in productivity, improving standards of living, rapid population growth and explosion in art, learning, science, scholarship and knowledge known as the Renaissance. Besides, this era coincided with the making of the modern state in Europe as the states system of Europe has extraordinary influence in the world beyond Europe. Indeed, as David Held has put the point sharply: "European expansion and development had a decisive role in shaping the political map of the world" (1992: 72). In particular, globalization itself became a major source of expansion of state activity and efficiency. Governments organized and reaped some of the fruits of the "discovery" and exploitation of non-European lands as it became essential to equip, plan and finance exploration and manage newly acquired posts and territories. The points which Qasim expressed in this travelogue and which he discussed with these European scholars revolved around the most pervasive issues at the time. These attitudes have been imparted from one generation to another up till the present time (al-Qaddouri 1995: 41, Hall and Gieben 1992).

In his Rihla, the author's representations of the Christians are infused with a sense of debasement and negation. There is the dichotomization of the "Self" and the "Other", the purpose of which is to underscore the superiority of the former over the latter. The use of these binary discursive constructions can be construed as practically an antidote to the plight he and his coreligionists went through under Philip III's constant pressures-cum-threats. In his "The Question of Occidentalism and Early Modern Morocco", whose main premises emanate from Michael Foucault's concept of classical "differentiation" as an explanation for the establishment of dichotomous discourses at the foundation of Western modernity, Nabil Matar postulates that Moroccan travellers did not make a line of structural separation between themselves and the European as Other. Moroccan travellers to Europe did not inscribe their encounters with the Europeans within "particular myths, visions and fantasies" which portray many European texts.

The Moroccan travellers to the "land of the Christians" and their accounts cannot be dealt with from the same prism through which the theoretical models European travel accounts have been studied and scrutinized by different postcolonial critics such as Edward Said, Gayatri Spivak, Mary Louise Pratt and Stephen Greenblatt. ${ }^{5}$ For example, most of the British travellers who made their peregrinations into Morocco during different periods of time showed their imperial ethos and solidified the concept of empire and its different apparatuses,

\footnotetext{
${ }^{5}$ Said Edward (1978) Orientalism. London: Routledge; Stephen Greenblatt (1991) Marvellous Possessions: The Wonders of the New World. Chicago: University of Chicago Press; Gayatri Spivak (1988) Can the Subaltern Speak? In Marxism and the interpretation of Culture, 271313. Urbana: University of Illinois Press; Mary Louise Pratt (1992) Imperial Eyes: Travel Writing and Transculturation. London: Routledge.
} 
becoming therefore an indispensable fodder for European colonizers who showed their hankering for far-flung and overseas territories. Quite the contrary, Moroccan travellers to Europe wrote empirical texts about the European Other in the same vein their predecessors had written accounts about the Islamic world. Besides, even when a writer such as Ahmad bin Qasim (al-Hajari) travelled to Europe with anger, hostility and a sense of angst, expressing his deep denunciation towards the Christians (nasara) for having expelled his forefathers and coreligionists from Al-Andalus, there are vivid instances throughout the whole account wherein the author showed wonders and mesmerizing tendencies towards the Christains, being kept open to the nasara and their innovations. AlHajari thought that it was incumbent upon him to persuade the Christian "others" about different religious matters which he believed that he mastered well.

While in "the land of Flanders," Qasim did not spare any effort to show his wonder of Holland, its cities, its culture, its people as well as its prince, simply because of the latter's empathy and sympathy with the Moriscos' cause and because of the fact that "[the Flemish] do not harm the Muslims, but are good to them." Qasim gets enchanted by the city of Amsterdam: "When we reached the city of Amsterdam, I saw the wonder of its magnificent buildings, its cleanliness, and its immense population. Its buildings were nearly similar to those of Paris in France. There was no city in the world with as many as ships as it had" (Matar 2003b: 32).

There are historico-religious reasons behind Qasim's wonderment and admiration of the Flemish. At the eve of the sixteenth century, the Spanish attempted to create a Christian empire and preside over it. Bolstered by the Pope, the Spanish king, Philip II, became the Emperor of the Catholic Christendom in 1519. Likewise, the Turks, at the same time, did their best to gather Muslims and their kings took the name of Islamic Khalifate immediately after their entrance into Egypt in 1517. The Spanish king felt that the Moriscos did plot against his religious regime with Muslims of the Ottoman Empire or with the Christians, especially the English and the Flemish. Put otherwise, the expulsion of the Moriscos was fed on by a particular interpretation of the Reconquista and was carried out in a context of confrontation with the Ottomans and Moroccans, at the same time that the religious struggles in Northern Europe had created a favourable atmosphere for a view of Spain as the champion of Catholicism and religious unity.

During this period, the Mediterranean basin was a place of interactions and sometimes of conflicts between different religions, ethnicities and cultures: we have the Moors, the Arabs, the Jews, the Amazighs, and the Turks. The outset of the seventeenth century was characterized by the increase of corsair activities as Barbary pirates were a big threat for the existence of the Spanish and the belief that these pirates, whom the expelled Moriscos enjoyed later, were a big threat towards the Spanish.

When Qasim moved from the city of Leyden to the city of Hague, he met the prince of Holland, Maurice of Nassan (1567-1625), who asked him the following question, "why did the sultan of Spain expel the Andalusians from his land?" Qasim's answer was based on the position of Spain during the Great 
Explorations; he also observed that the number of the Christians decreased: "among those [Catholic] Christians, there are large numbers of priests and monks and nuns, and by renouncing marriage, they leave no offspring," whereas the number of Andalusians was on the increase because "there were no priests or monks or nuns; rather they all married and increased by having children and by neither going to war nor out to sea" (Matar 2003b: 36). This situation was, Qasim argues, the main cause that prodded the Spanish King, Philip II, to give an order for a general census for all the Andalusians, "young and old, even those in the wombs of pregnant women: and none knew the secret reason for that. Seventeen years later," Qasim added, "another census was carried out just like the first one, and none knew the secret of that either [...] As soon as they discovered that they were on the increase, they ordered their expulsion" (Matar 2003b: 36).

Qasim wanted to know why the Prince of Holland showed his strong support for the Andalusians, and why the Prince suggested to him a naval support against Spain. He came to the conclusion that the people of Flanders wanted to solidify their independence against Spain. Besides, their strong attitudes towards the Spanish, whose Catholic tendencies were underpinned by the Papacy in Rome, lay behind the fact that the people of Flanders adopted the beliefs of the German religious leader Martin Luther (1483-1546):

Know that these Flanders...belong to the sultan of Andalus. But then, there appeared among them a learned man named Luther [Bultari] and another named Calvin [Qalbin]. Each wrote his views on the religion of the Christians- showing the falsification and deviation from the religion of our Sayyid Issa and the Gospel. They also wrote how the pope in Rome misleads people by [urging them] to worship idols and by interpolating the prohibition of marriage for priests and monks, and many other things. All the population of Flanders joined that religion, and they rebelled against their sultan, and continue in their rebellion until now. The inhabitants of the sultanate of the English are followers of this religion, and many in France [faranja] follow it too. (Matar 2003b: 32-33)

Notwithstanding the traveller clearly portrayed the European as "Other", separated geographically, culturally, religiously and ontologically, Nasir Adin ala alqawm al-kafirin is imbued with deep amity and mahaba (love/affection), a trope that is deployed extensively by the Moroccan envoy as well as by other emissaries who made their journeys to Europe. Matar argues that the Maghrebis of Morocco did not draw a line of structural separation between themselves and the European as Other. Matar proposes three reasons why early modern Maghrebi culture did not occidentalize the European: Islam accorded a place for the "prophet" of Christian culture; the concept of mahaba (love/affection) implicitly incorporated even cultural others into the Maghrebi imaginary; the late arrival of print culture to the Arabic writing world forestalled the circulation of stereotyping discourses (2003a). 
Qasim made his ambassadorial journey in the seventeenth century, and the century visitors belonged to an Islamic society that appeared as powerful and wealthy as the society of Europe. Neither Muslims nor Christians were put on the cultural or historical defensive during the European journey. Qasim admired the tidiness of Amsterdam and its orderly streets and the buildings of Paris, but he was not overwhelmed as Marrakech boasted the palace of al-Badi, an architectural marvel. He felt so much an equal that he may have viewed his journey as an act of theological and intellectual jihad against equal adversaries. For Matar, "While European writers all too often indulged in Orientalism, Arab writers did not construct a parallel 'Occidentalism'" (Matar 2003b: xxxviii).

Not only does Qasim depict his religious counterparts throughout his Rihlah, he also dedicates grateful statements to the Turks, who are delineated as the perfect foil to the Christians. He talked with wonder about their empire, and listed the main roles they played to preserve Islam, and he regarded them as the only power that could beset Europeans' colonial strong desire. The traveller manifested that the European did not distinguish between a Muslim and a Turk because this European viewed all Muslims as Turks: "in the land of the ifranj and in many other sultanates of the Christians, they call the Muslims Turk" (Matar 2003b: 31). This confusion can be attributed to the powerful position the Ottomans had in the Mediterranean as the latter did intervene in international issues and matters, a fact which always troubled and annoyed Europeans.

It was not only Qasim who represented the Turks positively; there were other Muslim scholars who adapted the same attitude as they saw in the Turks a strong defender of Islam against the European expansion that became threateningly pernicious for the Islamic entity. As a vivid example, we can bring to sharp focus the viewpoint of Ibn Abi Mahali, who was aware at the outset of the seventeen century of the European threats which were on the increase. He wrote to the Turks and advised them to be on full alert against what he called "the worshippers of the Cross." Qasim regarded the Ottomans as a rescuer and an ardent supporter of the Moriscos and their painful plight.

\section{Moriscos' Cause: A Lesson from History}

The Moriscos' plight is predominant in Qasim's travelogue, and the traveller wanted to give his account a civilizational dimension. As an injured Morisco, he dealt with and approached this account from different angles. During his visit to Egypt, Qasim told his stories to many people there, and one of them, Shaykh Sidi Ali al-Ughuri, a Maliki Egyptian jurist and a renowned Alim (savant/ scholar), who encouraged and advised him and praised his work, which means that the Moriscos' ordeal was not known at the time amongst most of Muslims (Al-Qaddouri 1995: 43). The Islamic settlement in Al-Andalus was, for him, perfectly normal as it was historical. Thus, we see him getting surprised by the Spanish decision to cruelly expel the people of Al-Andalus. He brought into sharper focus as an eyewitness his coreligionists' ordeal and dilemma to the extent that there were numerous of them who were burnt alive when they 
showed their affiliation. The envoy talked about Moriscos' painful experience because he was integral of it. This minority underwent all aspects of persecution and harsh treatments under the Spanish as the Christians killed/burnt any Morisco who had any relation to Islam.

The expulsion of the Moriscos constitutes a significant instance of ethnic, religious and political cleansing. It fed off an ideology firmly based on the idea that freedom of word and religion were incompatible with the functioning of a well-ordered society. It was an ideology which valued uniformity over diversity and argued in favour of the expulsion because it deemed the processes of complete cultural assimilation and full integration which it claimed to pursue to have failed. In more contemporary parlance, it justified the Expulsion because of the Moriscos' continued production of cultural difference. However, it is unlikely that full assimilation would ever have solved the problem, since this was a society which still placed great store by the notion of limpieza de sangre [cleanliness or purity of blood], an idea that was by then more than two hundred years old and had embedded itself deeply in Old Christian society. In fact, this obsession with limpieza de sangre originated with the great processes of mass conversion which took place in the Iberian Peninsula from the late fourteenth century onwards and brought an end to the legal existence of a plurality of religious groups with clearly defined boundaries whose presence had characterised the Peninsular Middle Ages. The obsession with limpieza de sangre (which had become almost inseparable from religious orthodoxy) carried with it the fear of cultural, political, religious and social infiltration, a fear that was equal to or greater than the feeling of failure brought about by the alleged lack of Morisco integration. The importance of this fear of infiltration, of the contamination associated with the inheritance of shame and the subsequent theological "stain," became obvious when Moriscos were ordered to leave the country even when they were able to prove that they were good Christians. The unnoticed return of many Moriscos and the way in which some of them stayed on in their places of origin (discussed in this volume by Vincent and Tueller, among others), show that they were often indistinguishable from their Old Christian neighbours in language, dress or social and religious behaviour, as is also demonstrated by the fact that Old Christians were sometimes able to pass themselves off as Moriscos. There is no doubt that genealogical descent from Muslims became the only argument for a purge which according to contemporary providentialist discourse was needed to avoid divine punishment.

The decision to expel the Moriscos followed more than a century in which Spain's rulers tried to eradicate not just the Islamic religious beliefs of the Moriscos, but their customs and cultural traditions. Public or private bathing, dances, the speaking of Arabic, circumcision and Muslim burial rites, even eating couscous were regarded as deviant acts and punished with fines, imprisonment and even execution. These efforts were led by the Inquisition, and they were not entirely unsuccessful (Carr 2011).

A lot of Moriscos did become "good and faithful Christians", either through resignation to the new status quo or genuine conviction. Others remained faithful to their Islamic religious beliefs and lived parallel lives, outwardly 
conforming to Catholicism while continued to worship as Muslims in secret. Such behaviour affirmed the prejudices of their Christian enemies and became a justification for further repression. This increasingly vicious circle of repression and defiance fatally undermined the possibility for coexistence even within the admittedly narrow terms demanded by Christian society. Philip III attempted to convert Moriscos to embrace the Spanish identity and purify it from all stains and impure aspects which were detrimental to Catholic/Hispanic identity by forcibly absorbing Spanish Muslims into Christian society. Indeed, Muslims were seen as a defilement of the Christian blood. In his "The Moriscos: A Lesson from History?", Matthew Car states:

The original "conversions" of the Moriscos were intended to eradicate an Iberian Islamic presence that was considered to be inimical to Spain's Catholic/Hispanic identity by forcibly absorbing Spanish Muslims into Christian society. But the more extremist anti-Morisco elements depicted Spain's Muslim population in quasi-racist terms as defilement of Christian 'blood,' who contaminated Christian society precisely because they were so closely interwoven with it. (Carr 2011: 12)

The Spanish king, Philip III, found in Moriscos' duplicity and dissimulation what justified his strong conflict with the Turks. Qasim subsumed in his travelogue the Spanish King's letter to his relative and successor in the city of Valencia. He ordered him to begin expelling the Andalusians because all the attempts to integrate them into the Spanish society by Christianizing them came to a complete fiasco. The date of the letter was the onset of the year 1609; it is worth quoting in some length thus:

You know that over the past many years, [we have tried] to guide, confirm and lead the New Christians of the Andalus, the inhabitants of this sultanate and that of the Castile, to our glorious religious and faith. But neither the great nor the small benefited because none of them is a true Christian. Scholars and reverent men have warned us of the danger of and evil that would befall us for turning a blind eye [ to the presence of those cryptoMuslims], and they have told us that the matter has to be corrected in order to please God and remove His anger against our community. They determined that, without doubt, it is permitted us to punish them in their persons and possessions, for by continuing in their misdeeds, they were judged and condemned as hypocrites and enemies of the divine and human majesty. It was fully within our power to punish them for the guilt and evil deeds they committed. Despite that, I chose to treat them with patience and leniency, without seeking vengeance. As a result, we ordered the august assembly, which I attended with all the scholars and nobility of that city, to find a new way to expel them from our kingdom. In that [meeting], we looked into the matter and confirmed that they [Moriscos] had sent emissaries to the Grand Turk in Istanbul and to Mulay Zaidan in Marrakech asking them for help, and reporting them that they had 150,000 Muslim men, just like 
those in the land of African Morocco. They also communicated with our maritime enemies in the northern region under the pole, who assured them of naval support. Meanwhile, the sultan of Istanbul had reached a peace agreement with the sultan of the Persians, who had fought against him. As for the sultan of Marrakech, he planned to conquer the land and occupy it. If they all agree with each other, we will find ourselves in [such a dire] situation that cannot be kept undisclosed. (Matar 2003b: 40-41).

For the expulsion to be possible the king and the members of his government needed the existence of an ideology that saw the Moriscos as incapable of integrating within Spanish society as Catholics and loyal subjects of the Spanish monarch. Without that ideology and without the existence of previous debates on the feasibility and legitimacy of the expulsion, neither the specific expulsion measure nor its justification would have been possible (Antonio Feros 2014: 61). According to Antonio Feros, the Moriscos continued to be Moriscos because society had isolated them, thus reinforcing their particular identity; they clung to it because society had forced them to do so, not because they were unable to change.

The expulsion of 1609-1614 was inevitable, for in the Iberian Peninsula there were two intransigent and inexorable entities. The Spanish Catholic church tried all the harder to impose its Catholic credos on Moriscos and make them conform to it by all means possible, whereas the Moriscos, on the other, refused by resorting to even adopting two double identities: apparently, they were Christians and they seemed to comply with the instructions of the church, but stealthily they adhered to their religion, Islam; these Moriscos had certain traditions and customs as their feelings oscillated between apparent Christianity and deep Islam. They were deported to different Maghrebi countries, especially Morocco, Algeria and Tunisia. Their feelings are a cluster of anger, nostalgia, relief, elegy and revenge even. Indeed, the expelled Moriscos, in Ellen G. Friedman's views, engaged in corsair activities against all the Christians in the Mediterranean basin:

The evidence strongly suggests a direct relationship between the expulsion and the significant increase in corsair activity on Spain's coasts in the seventeenth century. A corollary development of the early seventeenth century - one that various factors gave rise to but in which the Moriscos were implicated - was the movement, in large numbers, of Muslim corsairs into the Atlantic, where they threatened the northwest coasts of Spain and Portugal, as well as the Indies fleet and other Atlantic navigation. (Friedman 1983: xxiv)

A $16^{\text {th }}$ century Spanish time traveller in today's Europe might have been bewildered by the representation of Europe's Muslims as a collective threat to European secularism, tolerance and other cultural values - to say nothing of the often repeated references to Europe's "Judeo- Christian" roots. 
Sixteenth century Spanish officials regarded the Moriscos as "domestic enemies" with links to the Barbary corsairs and the Ottomans. Inquisitors regarded Morisco communities as bastions of covert Islam and nests of seditious speech. As in the sixteenth century, the depiction of Europe's Muslims as "suspect communities" tends to interpret cultural and religious difference - whether real or simply imagined - as an expression of defiance or intransigence. Muslim contacts with the Europeans in different periods of time starting from the second half of the sixteenth century, their contribution to culture and civilisation as well as their historical legacies. The main challenges that face Muslims in Europe: identity formation or fashioning, integration and Islamophobia, but today there is a widespread fear among most Europeans that Muslims and migrants are the source of a potential islamification and other problems related to identity. These travellers show in very detailed manners the transcultural encounter between Europeans and the Arabs, epitomized by these travellers and envoys, who visited Europe during different periods of time.

\section{Conclusion}

Ahmad bin Qasim al-Hajari's ambassadorial and polemical travel text The Book of the Protector of Religion against the Unbelievers (Nasir Adin ala alqawm al-kafirin) sheds light upon the main implications of the envoy's intellectual, cultural and theological interactions with the Christians in France and Holland at the beginning of the seventeenth century. As a Muslim from Dar al-Islam or "abode of Islam" and as an Andalusian-Moroccan in bilad al-nasara, Qasim was virtually rebuffed and confronted by Western Christian ifranj or ajam or ruum. Despite being an eyewitness of the Moriscos' plight under Philip III's intolerance towards Mulsims as a minority in Spain, Qasim al-Hajari does not deploy a discourse which is based on dichotomization, but he always talks about the possibility of mahabba (love/ affection) that can be maintained between the Nasara (Christians) and Muslims. This is justified in his deployment of debates, arguments, disputations and polemics as intellectual and epistemological tools to interact with the other. Despite hearing insulting views of Islam from Protestant and Catholic Christians, at no point did he subhumanize them; he castigated them and warned them of the consequences of their errors, but in his exchanges with them, he always appealed to rationality and to the Old and the New Testaments, which he quoted with reverence and deep respect. Besides, the reason behind the lack of an oppositional discourse in Arab-Islamic thought of the Maghreb is Muslim respect for the "Prophet" of the Christians. No Muslim writer ever described Jesus in the vilifying manner that Christian writers described the Prophet Mohammed. On the contrary, Moroccan writings include numerous references to the "hadiths" (Mohammed's main revelatory sayings) of the Prophet Mohammed that tell about "sayyidna Issa, alayhi al-salam" (our Master Jesus, peace be upon him), in which Jesus serves as an inspiration and guide to Muslims. Al-Hajari showed his angry fulminations in which he compared Christians with dogs. He deployed such words to draw certain analogies which 
appear especially in the writings of the exiled Moriscos who were bitter against the Christians for expelling them from their homes and depriving them of their children. And repeatedly, he and his coreligionists called on God to destroy the infidels: dammarahum Allah (may God destroy them) and khadhalahum Allah (may God weaken them) are frequently repeated invocations. Besides, Qasim's ambassadorial account teaches a very important historical lesson: if we adopt an assimilationist method towards the other, the result will be detrimental.

\section{Acknowledgements}

I would like to thank very much Dr Moulay Lmustapha Mamaoui for his unstinting support, invaluable pieces of advice and for leading the way. Many thanks also to Dr Khalid Chaouch for his encouragement. I want also to express a debt of gratitude to the anonymous reviewers from the Athens Journal of Mediterranean Studies for their constructive feedback and meticulous remarks. Finally, I am grateful to Mr. Ottoman Bychou for providing me with Nabil Matar's In the lands of the Christians.

\section{References}

Al-Qaddouri A (1995) Sufara Maghariba fi Ouropa 1610-1920 [Moroccan Ambassadors in Europe]. Rabat: Manchourat kuliyat al-Adab wal-Uloum al-Insaniya, No. 13.

Ashcroft B (2001) Postcolonial Transformation. London: Routledge.

Braudel F (1972-1973) The Mediterranean and the Mediterranean World in the Age of Philip II, trans. Siân Reynolds, vol 2. London: Collins.

Carr M (2011) The Moriscos: A Lesson from History? ARCHES Quarterly 4(8) (Spring/Summer): 10-17.

Clark GN (1944) The Barbary Corsairs in the Seventeenth Century. Cambridge Historical Journal 8(1): 22-35.

Colley L (2002) Captives: Britain, Empire, and the World, 1600-1850. New York: Anchor Brooks.

Feros A (2014) Rhetorics of the Expulsion. In M Garcia-Arenal, G Wiegers, C LopezMorillas, M Beagles (eds) The Expulsion of the Moriscos from Spain: A Mediterranean Diaspora. Leiden and Boston: Brill.

Friedman EG (1983) Spanish Captives in North Africa in the Early Modern Age. Madison: University of Wisconsin Press.

Goffman D (1990) Izmir and the Levantine World, 1550-1650. Seattle: University of Washington Press.

Hall S, Gieben B (eds) (1992) Formations of Modernity. Oxford: Blackwell Publishers Ltd.

Held D (1992) The Development of the Modern State. In S Hall, and B Gieben (eds) Formations of Modernity. Oxford: Blackwell Publishers LTD.

Lane-Poole S (1890) The Barbary Corsairs, $4^{\text {th }}$ ed. London: T. Fisher Unwin, Paternoster Square.

Latham R (ed) (1958) Marco Polo: The Travels. England: Penguin.

Leed E (1991) The Mind of the Traveller: From Gilgamesh to Global Tourism. New York: Basic Books. 
Lewis B (1993) Islam and the West. Oxford: Oxford UP.

Matar N (2003a) The Question of Occidentalism in Early Modern Morocco. In P Clare, MR Warren (eds) Postcolonial Moves: Medieval Through Modern, 153-170. Ingham. London: Palgrave Macmillan.

Matar N (2003b) In the Lands of the Christians: Arabic Travel Writing in the Seventeenth Century. London: Routledge.

Matar N (2014) British Captives from the Mediterranean to the Atlantic, 1563-1760. Boston: Brill.

Pratt ML (1992) Imperial Eyes: Travel Writing and Transculturation. London: Routledge. Said E (1978) Orientalism: Western Conceptions of the Orient. London: Routledge.

Spurr D (1993) The Rhetoric of Empire: Colonial Discourse in Travel Writing and Imperial Administration. London: Duke UP.

Tamimi A (1989) Al-Moriskiyoune al-andalussiyune wa al-massihiyune: al-mojabaha al jadaliya 1492-1640 [The Andalusian Moriscos and the Christains: The Argumentative Encounter 1492-1640]. Tunis: Manchourat al-majala al-Tarikhiya al-maghribiya.

Thompson C (2011) Travel Writing. London: Routledge.

Wallerstein I (1979) The Capitalist Economy. Cambridge: Cambridge University Press.

Windus J (1725) A Journey to Mequinez, The Residence of the Present Emperor of Fez and Morocco. London: J. Tonson.

Youngs T (1997) Editor's Preface. Literature and History 6(2) Special Issue "Placing Travel". 
